\title{
PHYTOCHEMICAL ANALYSIS AND ANTIBACTERIAL ACTIVITY OF SWIETENIA MAHAGONI: A HIGHLY MEDICINAL PLANT IN INDIA
}

\author{
MADHUMITHA S, VINOTHKUMAR D*, RAMESH BABU NG
}

Department of Biotechnology, Adhiyamaan College of Engineering, Hosur - 635 109, Tamil Nadu, India. Email: vinoth.vinopaul79@gmail.com Received: 08 June 2016, Revised and Accepted: 23 July 2016

\section{ABSTRACT}

Objectives: To evaluate the scientific basis for the plant, the antibacterial activities of extracts of the leaves were evaluated against some common bacterial species such as Staphylococcus aureus, Bacillus subtilis, and Escherichia coli. The study also investigated the phytochemical constituents of the plant and the effect of zone of inhibition on its anti-bacterial activity.

Methods: The phytochemical constituents of the dried powdered plant parts were extracted using aqueous and organic solvents (acetone, benzene, petroleum ether, water, and methanol). The anti-bacterial activity of the concentrated extracts was evaluated by determination of the diameter of zone of inhibition against bacterial species of B. subtilis, S. aureus, and E. coli using the disc diffusion method.

Results: Results of the phytochemical studies revealed the presence of tannins, saponins, flavonoids, phlobatanins, and alkaloid, and the extracts were against the bacterial species of B. subtilis, S. aureus, and E. coli.

Conclusion: Swietenia mahagoni has broad spectrum antibacterial activity and a potential source of new classes of antibiotics that could be useful for infectious disease chemotherapy and control.

Keywords: Swietenia mahagoni, Phytochemical compound, Antibacterial activity, Zone of inhibition.

(C) 2016 The Authors. Published by Innovare Academic Sciences Pvt Ltd. This is an open access article under the CC BY license (http://creativecommons. org/licenses/by/4. 0/) DOI: http://dx.doi.org/10.22159/ajpcr.2016.v9i6.13327

\section{INTRODUCTION}

Since times immemorial, medicinal plants have been used to maintain human health, especially with more intensive studies in the last decade for natural therapies [1]. Therefore, these were used for adding flavor and aroma to foods but also to provide antimicrobial properties [2,3] India is a continent with wide diversity. This diversity includes both flora as well as fauna. This variation is due to the varied climatic conditions, vegetation, topography, etc., resulting in enriched heterogeneity. As a result, many species are present with an increased medicinal value that is left untapped. Many of these species may possess medicinal values, domestic values, and therapeutic values $[4,5]$.

The medicinal and pharmaceutical properties of plants are due to the chemical substance they produce and store. These include compounds that are utilized as food by man and other animals and also other compounds that exert physiological effects on them. The usual term used to refer to these various chemical substances present in plants is constituents. These constituents which possess pharmacological properties are called active constituents. Phytochemistry is concerned with the chemical study of these plant constituents [6]. This study was evaluated to identify the phytochemicals present in the plant "Swietenia mahagoni and also to determine anti-bacterial activity."

\section{Plant description}

S. mahagoni is commonly known as "Ciminukku" in Tamil. It is an important medicinal plant belonging to the family Symphoremataceae. S. mahagoni is a medium-sized semi-evergreen tree growing $30-35 \mathrm{~m}$ (98-115 ft) tall. The leaves are pinnate, $12-25 \mathrm{~cm}$ (4.7-9.8 inch) long, with four to eight leaflets, each leaflet $5-6 \mathrm{~cm}$ (2.0-2.4 inch) long and $2-3 \mathrm{~cm}(0.79-1.18 \mathrm{inch})$ broad; there is no terminal leaflet. The flowers are small, produced in panicles. The fruit is a woody capsule 5-10 cm (2.0-3.9 inch) long and 3-6 cm (1.2-2.4 inch) broad, containing numerous winged seeds.

\section{Medicinal properties}

The bark extracts are used as an astringent to treat wounds. Furthermore, it is used as a substitute for Cinchona bark in the West Indies. The bark contains 15\% Tannin, the wood 6\%. The seeds have been reported to contain a bitter substance; mahoganin, 7-deactyl-7oxogedunin, cyclomahogenol, and 6-hydroxymethyl angolensate are also present. Tetranortriterpenoids have been isolated from cotyledons and seeds. The ether extract of the leaves inhibits platelet activity factor (PAF) - induced platelet aggregation [7]

\section{METHODS}

\section{Collection of leaves}

Fresh leaves were collected from Adhiyamaan College of Engineering garden, Hosur, Krishnagiri, Tamil Nadu. The leaves were washed thoroughly 2-3 times with running water and distilled water, leaves were then air dried on blotter under shade.

\section{Preparation of extracts}

Acetone, benzene, petroleum ether, and methanol extracts were prepared in Soxhlet's apparatus. Soxhlet's extract was carried out at room temperature. $5 \mathrm{~g}$ of dried leaf powder of $S$. mahagoni is taken in a thimble and subjected to extraction in Soxhlet's apparatus at room temperature using acetone, benzene, petroleum ether, water, and methanol. The extract obtained was filtered through Whatman No. 1 filter paper and stored in airtight containers for further studies.

\section{Phytochemical screening}

Chemical tests were carried out on the acetone, methanol, benzene, petroleum ether, and water extracts for the qualitative determination of phytochemical constituents as described by Harbone [8], Trease and Evans [9], and Sofowara [5]

\section{Test for alkaloid}

About $3 \mathrm{ml}$ of aqueous extract was stirred with $3 \mathrm{ml}$ of 1\% HCL on steam bath. Mayer and Wagner's reagent was then added to the extract. 
Turbidity of the resulting precipitate was taken as evidence for the presence of alkaloid.

\section{Test for tannins}

About $3 \mathrm{ml}$ of the aqueous extract was stirred with $3 \mathrm{ml}$ of distilled water, and few drops of $\mathrm{Fecl}_{3}$ solution were added. The formation of green color precipitate was an indication of the presence of Tannins.

\section{Test for saponins}

About $3 \mathrm{ml}$ of the aqueous extract was shaken vigorously with an equal volume of distilled water in a test tube and warmed. The formation of stable foam was taken as an indication of the presence of saponins.

\section{Test for phlobatannins}

About $3 \mathrm{ml}$ of aqueous extract was added to $2 \mathrm{ml}$ of $1 \%$ HCL and the extract was boiled. Deposition of a red precipitate was taken as evidence for the presence of phlobatannins.

\section{Test for flavonoids}

To $3 \mathrm{ml}$ of aqueous extract, $1 \mathrm{ml}$ of $10 \%$ lead acetate solution was added. The formation of a yellow precipitate was taken as a positive result for flavonoids.

\section{Test for terpenoids}

About $3 \mathrm{ml}$ of the extract was dissolved in $2 \mathrm{ml}$ of chloroform and evaporated to dryness. $2 \mathrm{ml}$ of concentrated sulfuric acid was then added and heated for about 2 minutes. Development of grayish color indicates the presence of terpenoids.

\section{Medium for microbial growth}

The nutrient agar medium was prepared and sterilized for bacteria. Three bacterial species such as Staphylococcus aureus, Bacillus subtilis, and Escherichia coli were obtained from the Microbiology Research Centre, Department of Microbiology, MGR College, Hosur. The bacterial strains were used in agar disc diffusion method at the respective temperatures at $37^{\circ} \mathrm{C}$ for $48-72 \mathrm{hrs}$ for mother culture. The leaf extract was taken separately in various concentrations of 25, 50, 75 and $100 \mu \mathrm{l}$. They were kept under incubation and later the plates were observed for zone formation, and the length $(\mathrm{mm})$ of the zone was measured.

\section{RESULTS}

\section{Phytochemical screening}

The phytochemical constituent of leaf of S. mahagoni was investigated. From Table 1, it was shown that the presence of alkaloids can be determined in all the solvents. The leaf extract was found to constitute alkaloid, tannins, saponins, phlobatannins, flavonoids, and terpenoids. The phytochemical result obtained from above test shown that the solvent petroleum ether demonstrates the presence of the above phytochemicals present in S. mahagoni leaf extract. Furthermore, the highest result was obtained in petroleum ether leaf extract of S. mahagoni $(16.3 \mathrm{~mm})$ zone of inhibition.

\section{Antibacterial activity}

The antibacterial activity was determined by the agar disc diffusion method. In this study, E. coli, B. subtilis, and S. aureus were used for assessing the antibacterial activity. The assessment of antibacterial activity was based on the measurement of diameter of inhibition zone formed by dissolving the plant leaf extract in methanol and other solvents used in the activity.

The results of antimicrobial activity of methanolic leaf extract of S. mahagoni are summarized in Table 2. Methanolic leaf extract showed zone of inhibition for B. subtilis. However, the methanolic leaf extract shows the least antibacterial activity on $E$. coli with $(11.6 \mathrm{~mm})$ zone of inhibition and S. aureus with (13.4 mm) zone of inhibition in $100 \%$ concentrations was shown in Table 2.

The results of antimicrobial activity of benzene leaf extract of S. mahagoni are summarized in Table 3. Benzene leaf extract shows
Table 1: Phytochemicals in leaf extract of S. mahagoni

\begin{tabular}{llllll}
\hline Phytochemicals & A & M & B & PE & W \\
\hline Alkaloid & + & + & + & + & + \\
Tannins & - & + & - & + & - \\
Saponins & - & - & + & + & - \\
Phlobatannins & + & - & + & + & - \\
Flavonoids & + & + & - & + & - \\
Terpenoids & - & + & + & + & - \\
\hline
\end{tabular}

S. mahagoni: Swietenia mahagoni

Table 2: Methanol leaf extract of S. mahagoni

\begin{tabular}{llll}
\hline Concentration (\%) & $\begin{array}{l}\text { Staphylococcus } \\
\text { aureus }\end{array}$ & $\begin{array}{l}\text { Bacillus } \\
\text { subtilis }\end{array}$ & $\begin{array}{l}\text { Escherichia } \\
\text { coli }\end{array}$ \\
\hline 25 & $8.2 \pm 0.6$ & $7.2 \pm 0.9$ & $8.6 \pm 1.6$ \\
50 & $9.9 \pm 0.8$ & $8.9 \pm 0.3$ & $9.4 \pm 0.7$ \\
75 & $11.4 \pm 1.2$ & $11.1 \pm 0.9$ & $10.9 \pm 1.8$ \\
100 & $13.2 \pm 0.6$ & $12.9 \pm 1.6$ & $11.6 \pm 0.9$ \\
\hline
\end{tabular}

S. mahagoni: Swietenia mahagoni, S. aureus: Staphylococcus aureus,

B. subtilis: Bacillus subtilis, E. coli: Escherichia coli

Table 3: Benzene leaf extract of $S$. mahagoni

\begin{tabular}{llll}
\hline Concentration (\%) & $\begin{array}{l}\text { Staphylococcus } \\
\text { aureus }\end{array}$ & $\begin{array}{l}\text { Bacillus } \\
\text { subtilis }\end{array}$ & $\begin{array}{l}\text { Escherichia } \\
\text { coli }\end{array}$ \\
\hline 25 & $8.2 \pm 0.6$ & $7.2 \pm 1.3$ & $8.6 \pm 0.9$ \\
50 & $9.9 \pm 0.3$ & $8.9 \pm 0.7$ & $9.4 \pm 1.6$ \\
75 & $11.4 \pm 1.2$ & $11.1 \pm 0.9$ & $10.9 \pm 1.8$ \\
100 & $13.2 \pm 0.3$ & $12.9 \pm 0.6$ & $11.6 \pm 0.4$ \\
\hline
\end{tabular}

S. mahagoni: Swietenia mahagoni, S. aureus: Staphylococcus aureus, B. subtilis: Bacillus subtilis, E. coli: Escherichia coli

strongest antibacterial activity on $S$. aureus with $(13.2 \mathrm{~mm})$ zone of inhibition. However, the benzene leaf extract showed the least antibacterial activity on $E$. coli with $(11.6 \mathrm{~mm})$ zone of inhibition and B. subtilis with (12.9 mm) zone of inhibition in $100 \%$ concentrations was shown in Table 3.

The results of antimicrobial activity of petroleum leaf extract of S. mahagoni are summarized in Table 4. Petroleum leaf extract shows strongest antibacterial activity on $B$. subtilis with $(15.4 \mathrm{~mm})$ zone of inhibition. However, the petroleum leaf extract shows the least antibacterial activity on E. coli with $(12.2 \mathrm{~mm})$ zone of inhibition and $S$. aureus with $(13.1 \mathrm{~mm})$ zone of inhibition in $100 \%$ concentrations as shown in Table 4.

The results of antimicrobial activity of water leaf extract of S. mahagoni are summarized in Table 5. Water leaf extract shows strongest antibacterial activity on $B$. subtilis with $(16.1 \mathrm{~mm})$ zone of inhibition. However, the water leaf extract shows the least antibacterial activity on E. coli with $(11.8 \mathrm{~mm})$ zone of inhibition and $S$. aureus with $(13.5 \mathrm{~mm})$ zone of inhibition in 100\% concentrations as shown in Table 5.

The results of antimicrobial activity of acetone leaf extract of S. mahagoni are summarized in Table 6. Acetone leaf extract shows strongest antibacterial activity on $B$. subtilis with $(16.3 \mathrm{~mm})$ zone of inhibition. However, the acetone leaf extract shows the least antibacterial activity on E. coli with $(13.2 \mathrm{~mm})$ zone of inhibition and S. aureus with $(15.4 \mathrm{~mm})$ zone of inhibition in $100 \%$ concentrations was shown in Table 6.

Phytochemical analysis and antibacterial analysis of the leaves of S. mahagoni was successfully carried out. These results are in agreement with the results of other works [10].

\section{DISCUSSION}

In the study of natural products, the phytochemical analysis is a key tool to investigate the chemical composition and establish the quality of a plant 
Table 4: Petroleum ether leaf extract of $S$. mahagoni

\begin{tabular}{llll}
\hline Concentration (\%) & $\begin{array}{l}\text { Staphylococcus } \\
\text { aureus }\end{array}$ & $\begin{array}{l}\text { Bacillus } \\
\text { subtilis }\end{array}$ & $\begin{array}{l}\text { Escherichia } \\
\text { coli }\end{array}$ \\
\hline 25 & $8.3 \pm 1.6$ & $8.9 \pm 0.8$ & $5.3 \pm 0.4$ \\
50 & $9.7 \pm 1.2$ & $10.4 \pm 0.2$ & $8.4 \pm 0.9$ \\
75 & $11.3 \pm 0.7$ & $12.8 \pm 1.4$ & $11.1 \pm 0.5$ \\
100 & $13.1 \pm 1.8$ & $15.4 \pm 0.9$ & $12.2 \pm 1.1$ \\
\hline
\end{tabular}

S. mahagoni: Swietenia mahagoni, S. aureus: Staphylococcus aureus,

B. subtilis: Bacillus subtilis, E. coli: Escherichia coli

Table 5: Water leaf extract of S. mahagoni

\begin{tabular}{llll}
\hline Concentration (\%) & $\begin{array}{l}\text { Staphylococcus } \\
\text { aureus }\end{array}$ & $\begin{array}{l}\text { Bacillus } \\
\text { subtilis }\end{array}$ & $\begin{array}{l}\text { Escherichia } \\
\text { coli }\end{array}$ \\
\hline 25 & $7.8 \pm 0.4$ & $9.5 \pm 1.2$ & $6.2 \pm 1.8$ \\
50 & $10.1 \pm 0.9$ & $10.9 \pm 0.6$ & $7.3 \pm 0.4$ \\
75 & $12.4 \pm 0.3$ & $11.9 \pm 1.2$ & $10.8 \pm 0.9$ \\
100 & $13.5 \pm 0.6$ & $16.1 \pm 0.5$ & $11.8 \pm 1.4$ \\
\hline
\end{tabular}

S. mahagoni: Swietenia mahagoni, S. aureus: Staphylococcus aureus,

B. subtilis: Bacillus subtilis, E. coli: Escherichia coli

Table 6: Acetone leaf extract of S. mahagoni

\begin{tabular}{llll}
\hline Concentration (\%) & $\begin{array}{l}\text { Staphylococcus } \\
\text { aureus }\end{array}$ & $\begin{array}{l}\text { Bacillus } \\
\text { subtilis }\end{array}$ & $\begin{array}{l}\text { Escherichia } \\
\text { coli }\end{array}$ \\
\hline 25 & $9.4 \pm 1.2$ & $8.2 \pm 0.6$ & $7.3 \pm 0.4$ \\
50 & $11.2 \pm 0.8$ & $11.3 \pm 1.4$ & $9.8 \pm 0.9$ \\
75 & $13.6 \pm 0.5$ & $14.6 \pm 0.8$ & $11.3 \pm 1.4$ \\
100 & $15.4 \pm 1.8$ & $16.3 \pm 1.1$ & $13.2 \pm 0.6$ \\
\hline
\end{tabular}

S. mahagoni: Swietenia mahagoni, S. aureus: Staphylococcus aureus,

B. subtilis: Bacillus subtilis, E. coli: Escherichia coli

species and define its potential as a source of bioactive molecules [11] Plants are important sources of potentially useful substances for the development of new therapeutic agents. Various phytochemical compounds as secondary metabolites have been implicated in plants as the conferment of antibacterial activities $[12,13]$. The above phytochemical study was discussed with some earlier phytochemical works. The previous study was done in the seeds of $S$. mahagoni demonstrated that the methanolic extracts of $S$. mahagoni seeds contained the total phytochemical compounds and indicating major antioxidant activity [14] Similarly, another earlier phytochemical study was done in flower and bark of $S$. mahagoni revealed that all the phytochemicals present in methanolic extract and also it indicating high antimicrobial activity [15]. Compared with the earlier studies of $S$. mahagoni, this study evaluated that the leaf extract of $S$. mahagoni showed to be containing of all phytochemicals (alkaloid, tannins, saponins, phlobatannins, flavonoids, and terpenoids) in petroleum ether extracts and also high antimicrobial activity was obtained in acetone leaf extracts with $16.3 \mathrm{~mm}$ zone of inhibition.

\section{CONCLUSION}

This study indicated that $S$. mahagoni is a good source of various phytochemicals such as alkaloid, flavonoids, phlobatannins, saponins, tannins, and terpenoids. The current study shows that the plant S. mahagoni imparts high therapeutic properties that can used to cure malaria, anemia diarrhea, fever, and dysentery. Furthermore, the bark extract is used as an astringent to treat wounds. The antibacterial activity of $S$. mahagoni was clearly shown in this study against B. subtilis, E. coli and S. aureus. Hence, the therapeutic value of $S$. mahagoni was determined using phytochemical analysis of leaf extract and antibacterial activity of the leaf extract using the above micro-organisms.

\section{ACKNOWLEDGMENTS}

Authors are thankful to the management and the Principal of Adhiyamaan College of Engineering, Hosur for providing all the necessary facilities.

\section{REFERENCES}

1. Gislene GF, Juliana L, Paulo CF, Giuliana LS. Antibacterial activity of plant extracts and phytochemicals on antibiotic resistant bacteria. Braz J Microbiol 2000;31(4):247-56.

2. Nanasombat S, Prasertsin V, Graisin K, Shain H, Thanaboripat B. Efficacy of New Enzyme - Linked Immunosorbent Assay for Rapid Detection of Salmonella in Foods. Vol. 51. Bangkok: Government Pharmaceutical Organization Report; 2002. p. 53-7.

3. Chaudhry NM, Tariq P. Bactericidal activity of black pepper, bay leaf, aniseed and coriander against oral isolates. Pak J Pharm Sci 2006;19(3):214-8.

4. Indu MN, Hatha AA, Abirosh C. Antimicrobial activity of some of the South - Indian SPICES against serotypes of Escherichia coli. Braz J Microbiol 2006;37(2):153-8.

5. Sofowara A. Medicinal Plant and Traditional Medicine in Africa. Textbook of Pharmacognosy. $14^{\text {th }}$ ed. Ibadan: Spectrum Books Limited; 1993. p. 50-60.

6. Evans WC. Trease and Evans Pharmacognosy. $15^{\text {th }}$ ed. London: W.B Saunders Company Ltd.; 2002. p. 137-9.

7. Pradeep A, Dinesh M, Govindaraj A, Vinothkumar D, Ramesh Babu NG. Phytochemical analysis of some important medicinal plants. Int J Biol Pharm Res 2014;5(1):48-50.

8. Harbone JB. Phytochemical Methods: A Guide to Modern Techniques of Plant Analysis. 13 ${ }^{\text {th }}$ ed. London: Chapman and Hall, Ltd.; 1973. p. $5-15$.

9. Trease GE, Evans WC. Trease and Evans Pharmacognosy: A Physician's Guide to Herbal Medicine. $13^{\text {th }}$ ed. London: Bailliere Tindall; 1989. p. 26-35.

10. Khare CP. Indian Medicinal Plants. Berlin/Heidelberg: Springer-Verlag; 2007. p. 633-4. ISBN: 978-0-387-70637-5.

11. Zhao J, Deng JW, Chen YW, Li SP. Advanced phytochemical analysis of herbal tea in China. J Chromatogr A 2013;1313:2-23.

12. Sule A, Ahmed QU, Samah OA, Omar MN, Hassan NM, Kamal ZM. Bioassay guided isolation of antibacterial compounds from Andrographis paniculata. Am J Appl Sci 2011;8(6):525-34.

13. Cao Y, Wei X, Xu H, Tang W. Antifungal properties of methanol extract and its active compounds from Brickellia rosmarinifolia Vent. Fitoterapia 2010;81(8):1176-9.

14. Hajra S, Mehta A, Pandey P. Phenolic compounds and antioxidant activity of Swietenia mahagoni seeds. Int J Pharm Pharm Sci 2011;3(5):431-4.

15. Ashikur Rahman SM, Akter M, Hira TE. Antioxidant and antimicrobial activities of flower and bark extract of Swietenia mahagoni(L). Jacq. J Pharmacogn Phytochem 2014;2(6):185-8. 